\title{
BATS OF RPPN PÉ DE SERRA, A RESERVE OF CAATINGA IN THE NORTHEASTERN BRAZIL
}

\author{
MORCEGOS DA RPPN PÉ DE SERRA, UMA RESERVA DA CAATINGA NO NORDESTE DO BRASIL
}

Fábio C. Falcão

Valéria C. Tavares ${ }^{2}$

\begin{abstract}
Caatinga is the least protected among all biomes within Brazil, and a vast part of its total area is located at the Bahia state, northeastern Brazil. Mammal inventories of Caatinga areas are sparse, and it harbors one of the two poorest known bat fauna within Brazil, as less than $10 \%$ of its extension has been minimally sampled. In this paper we report the results of the first bat inventory conducted at the Reserva Particular do Patrimônio Natural Pé de Serra, Ibotirama, NE Brazil, a protected area of Caatinga in the São Francisco river Valley and highlight the potential importance of this reserve for the conservation of the Caatinga biome of Brazil. Using mist-nets and searching for diurnal roosts, we recorded 55 bats in the RPPN Pé de Serra, belonging to 11 species, 10 genera and 2 families. The most frequently captured species was Artibeus planirostris (Spix, 1823), followed by Carollia perspicillata (Linnaeus, 1758) and Platyrrhinus lineatus (É. Geoffroy, 1810). Collecting bats at their diurnal roosts allowed to the first record of Saccopteryx leptura (Schreber, 1774) for the Bahia state and the record of Chrotopterus auritus (Peters, 1856) representing one of a few records of this species for the Caatinga biome. Our data can be useful to reinforce the urge to create new reserves to protect the Caatinga biome, in order to conserve and restore the habitat remnants, and to enable connectivity between protected areas.
\end{abstract}

Keywords: Chiroptera, mammals, distribution, species richness.

\section{Resumen}

Murciélagos de la RPPN Pé de Serra, una reserva de la Caatinga en el nordeste de Brasil. La Caatinga es el bioma menos protegido de Brasil, y una gran parte de su área total está localizada en el estado de Bahia, nordeste brasileño. Los inventarios de mamíferos en el área de Caatinga son escasos, y el bioma alberga una de las faunas más pobres de murciélagos, lo que puede ser resultado de sub-muestreo, ya que menos del 10\% de su extensión fue mínimamente muestreada. En este artículo comunicamos los resultados del primer inventario de murciélagos conducido en la Reserva Particular del Patrimonio Natural Pé de Serra, Ibotirama, nordeste de Brasil, un área protegida de Caatinga en el Valle del Río São Franscisco, y destacamos la potencial importancia de esta reserva para la conservación del bioma Caatinga de

1 Tetrapoda Consultoria Ambiental. Rua Joana Angélica, 131, sl.2B, Una, Bahia, Brasil. CEP: 45.690-ooo. (falcaobio@hotmail.com) https://orcid.org/oooo-0oo2-2748-7117

2 Laboratório de Mamíferos, MAME, Departamento de Sistemática e Ecologia, CCEN/DSE, Universidade Federal da Paraíba, UFPB, Campus I, João Pessoa, Paraíba, Brasil. CEP 58059-90o. (val.c.tavares@gmail. com) https://orcid.org/oooo-00o3-0966-0139 (correspondence author) 
Brasil. Por medio de capturas con redes de neblina y búsquedas por abrigos diurnos, registramos 55 murciélagos en la RPPN Pé de Serra, pertenecientes a las 11 especies, 10 géneros y 2 familias. La especie más capturada es Artibeus planirostris (Spix, 1823), seguida por Carollia perspicillata (Linnaeus, 1758) y Platyrrhinus lineatus (Geoffroy, 1810). Las colectas en abrigos diurnos permitieron el primer registro de Saccopteryx leptura (Schreber, 1774) para el estado de Bahia, y el registro de Chrotopterus auritus (Peters, 1856), el cual representa uno de los primeros registros para el bioma de la Caatinga. Este y otros estudios discutidos en este trabajo proporcionan evidencias sobre la importancia de la creación de nuevas áreas protegidas en el bioma Caatinga, para conservar y restaurar los hábitats restantes y aumentar la conectividad de las áreas protegidas.

Palabras-clave: Chiroptera, mamíferos, distribución, riqueza de especies.

\section{Resumo}

A Caatinga é o bioma menos protegido do Brasil, e uma grande parte de sua área total está localizada no estado da Bahia, nordeste brasileiro. Inventários de mamíferos na área da Caatinga são esparsos, e o bioma abriga uma das faunas mais pobres de morcegos, o que pode ser resultado de sub-amostragem, uma vez que menos de $10 \%$ de sua extensão foi minimamente amostrada. Neste artigo comunicamos os resultados do primeiro inventário de morcegos conduzido na Reserva Particular do Patrimônio da Natural Pé de Serra, Ibotirama, nordeste do Brasil, uma área protegida de Caatinga no Vale do Rio São Franscisco, e destacamos a potencial importância desta reserva para a conservação do bioma Caatinga do Brasil. Por meio de capturas com redes-deneblina e buscas por abrigos diurnos, nós registramos 55 morcegos na RPPN Pé de Serra, pertencentes à 11 espécies, 10 gêneros e 2 famílias. A espécie mais capturada doi Artibeus planirostris (Spix, 1823), seguido por Carollia perspicillata (Linnaeus, 1758) e Platyrrhinus lineatus (É. Geoffroy, 1810). As coletas em abrigos diurnos permitiram o primeiro registro de Saccopteryx leptura (Schreber, 1774) para o estado da Bahia, e o registro de Chrotopterus auritus (Peters, 1856), o qual representa um dos primeiros registros para o bioma da Caatinga. Este e outros estudos discutidos neste trabalho fornecem evidências sobre a importância da criação de novas áreas protegidas no bioma Caatinga, de forma a conservar e restaurar os habitats remanescentes e aumentar a conectividade das áreas protegidas.

Palavras-chave: Chiroptera, mamíferos, distribuição, riqueza de espécies.

\section{INTRODUCTION}

The Caatinga biome is completely nested in the Brazilian territory occupying an area estimated to approximately $844,453 \mathrm{~km}^{2}$ (IBGE, 2004). Unfortunately, recent estimates indicate that $30 \%$ to $52 \%$ of the Caatinga has been replaced by pastures or agriculture, and that the Caatinga is the least protected among all biomes within Brazil (Leal et al. 2005). A vast part of the total Caatinga area (approximately 30\%, or 
$249,500 \mathrm{~km}^{2}$ ) is located in the Bahia state, northeastern Brazil. Mammal inventories of Caatinga areas are sparse (Brito et al. 2009) but recent data has revealed that the Caatinga mammalian fauna might actually be richer than previously thought, with nearly 153 species, including at least 10 endemic mammals (Lewinsohn 2006). According to Bernard et al. (2011) the Caatinga harbors one of the two poorest known bat fauna within Brazil, as less than $10 \%$ of its extension has been minimally surveyed. To date at least 82 species of bats were recorded for the Caatinga biome, including the endemic genus and species Xeronycteris vieirai (Gregorin and Ditchfield 2005, Paglia et al. 2012; Moratelli and Dias 2015; Feijó et al. 2015 a,b; Rocha et al. 2015, 2018, Carvalho-Neto et al. 2017).

Records of bats from the Bahia state of Brazil have been relatively sparse and most inventories were restricted to the humid coastal region in Atlantic forest until very recently (Faria, 2006; Faria et al. 2006). More recent surveys of the caatinga bats have been reported to localities within the Parque Nacional da Chapada Diamantina (e.g. Gregorin \& Mendes 1999, Sbragia \& Cardoso 2008), a "humid island" in Caatinga (sensu Sá et al. 2003: 24), from several localities distributed in the southwestern and southeastern Bahia (Lapenta and Bueno 2015), and from the caatingas of Caetité (Soares et al. 2018).

In this paper we report the results of a first bat inventory conducted at the Reserva Particular do Patrimônio Natural (RPPN) Pé de Serra, Ibotirama, NE Brazil, a protected area of caatinga in the São Francisco River Valley, and highlight the potential importance of the small reserves such as the RPPN Ibotirama for the conservation of the Caatinga biome of Brazil.

\section{METHODS}

\section{Study site}

The RPPN Pé de Serra (1,259 ha) is located in the municipality of Ibotirama (12 ${ }^{\circ} 8^{\prime}$ oo" S, $43^{\circ} 13^{\prime}$ oo" W; Fig. 1), inserted in the highly xerophylic vegetation domains of the Caatinga (Sá et al., 2003). The clime is Aw type, equatorial savannahs with a dry winter, according to Köppen classification (Kottek et al. 2006).

We conducted bat captures during the winter, the drier season yearly, from September 14 to 18 , and in the summer season from February 16 to 19, 2008. We used ground-level mist-nets $(6,9$ and $12 \times 3 \mathrm{~m})$ kept open five hours/night beginning at sunset to capture bats. Most nets were set close to forest edges and to the water to improve chances of getting a larger volume of captures (Kunz and Kurta 1988), and near to fruit crops such as cashew and mango trees. We estimated capture efforts according to the calculations suggested by Straube and Bianconi (2002).

Bats were identified in the field using several identification keys (Vizotto and Taddei 1973, Simmons and Voss 1998, Lim and Engstrom 2001, Gardner 2007). 
The following data was collected from each individual captured: forearm length $(\mathrm{mm})$, body mass $(\mathrm{g})$, sex, reproductive status through observation of external characteristics, and age based in the ossification of digital epiphyses. Individuals were also categorized in the feeding guilds frugivore, omnivore, sanguinivore, nectarivore, gleaning insectivore, aerial insectivore and carnivore (Wilson, 1975, Kalko 1997, Schnitzler and Kalko 1998). Taxonomy followed Nogueira et al. (2014).

We evaluated the degree of completeness of our inventory with randomized (500x) sample-based species accumulation curves (Gotelli and Colwell 2001) and estimated the number of species expected to occur at the site using first-order Jackknife estimator. We used EstimateS 9.1.o (Colwell 2013) to make the calculations and Biodiversity Pro (McAleece et al. 1997) to plot rank abundance curves. All individuals collected were preserved in $70 \%$ alcohol and sent to be deposited in the mammal collection at Alexandre Rodrigues Ferreira of the Universidade Estadual de Santa Cruz, Ilhéus, northeastern Brazil.

\section{RESULTS}

We captured a total of 55 individuals in the RPPN Pé de Serra from 9 species, 8 genera, and 2 families employing a total of $6,525 \mathrm{~m}^{2}$.h of capture efforts (Tab. 1). We also recorded two species by diurnal roosting search, totalizing 11 species recorded for the RPPN.

When searching for diurnal roosts we found two individuals of Saccopteryx leptura at the edge of a crevice near the area known as "Mangueiras", and a small colony of six individuals of Glossophaga soricina near an old mining crystal cave.

The results obtained with mist-net capturing methods represent approximately $71 \%$ of the local expected richness (Jackknife $1=15.4 \pm 3.0$ ), and the species-accumulation curve does not seem to reach stabilization to an asymptote (Fig. 2). The rank abundance curve revealed a few dominant species, and several species represented by a low number of records (Fig. 3).

The most frequently captured species was Artibeus planirostris with nearly $27 \%$ of the captures, followed by Carollia perspicillata (20\%) and Platyrrhinus lineatus (16\%). Frugivores formed the richer ensemble (36\% of captured species), followed by aerial insectivorous ( $18 \%)$, with the remainder $9 \%$ representing other feeding ensembles (Tab. 1).

\section{DISCUSSION}

Bat species richness and abundance patterns in the caatingas of Ibotirama were similar to those found in the caatingas of the Parque Nacional Serra das Confusões, in Piauí (Gregorin et al. 2008). On the other hand, the richness of bats 
from Ibotirama that we were able to document were comparatively higher than that of the caatingas of the Planalto da Conquista (Falcão et al. 2005) and the caatingas of Caetité, in southwest of Bahia (Soares et al. 2018). The Parque Nacional Serra das Confusões and RPPN Pé de Serra reserves are less fragmented than the Planalto da Conquista region (F. C. Falcão pers. obs.), and probably are also more conserved than the Caetité region that harbors no conservation units, which may have contributed to those differences.

Most individuals captured (approx. 75\%) were frugivores, primarily because of sampling bias introduced with the use of ground-level mist-nets but also because frugivore phylostomids are abundant components of the neotropical bat fauna (Kunz \& Kurta 1988; McSwiney et al. 2008). A high richness of insectivores in the caatinga have been recorded by several authors (e.g. Gregorin et al. 2005, Zeppelini et al. 2017), and that illustrates the need of using acoustic techniques, including echolocation recordings, and increasing efforts to diurnal roost searching to a broad sampling of the local diversity.

A brief survey of bats at their roosts allowed to the first record of the species Saccopteryx leptura for the Bahia state (see Peracchi and Nogueira 2007, Tavares et al. 2008, Lapenta and Bueno 2015, Carvalho-Neto et al. 2017), and to the record of Glossophaga soricina in a crystal mine, which has been already reported in other parts of its distribution (Alvarez et al. 1991).

Captures of micronycterines such as Micronycteris minuta, and some phylostomines such as Chrotopterus auratus may be indicative of relatively less disturbed environments, as they have been considered indicative of habitat quality (Fenton et al. 1992, Medellin et al. 2000, Schulze et al. 2000, Faria 2006, Jones et al. 2009). The phyllostomine bat Chrotopterus auritus is the second largest Neotropical bat species, feeding on small rodents, birds, lizards, other species of bats, insects and fruits (Giannini and Kalko 2004). In Bahia, there are records of C. auritus mostly in forested and/or karstic areas including the interior of large fragments of forests, caves in the Pardo River Basin (Faria et al. 2006) in the southern part of the state, and a few in drier regions such as the Chapada Diamantina, central part of Bahia state (Gregorin and Mendes 1999). Within the Brazilian Caatinga biome C. auritus has been previously recorded in different phytophysiognomies, such as the dry forests of Jaíba, northern Minas Gerais (Silva et al. 2003; Tavares et al. 2008), in the valley of the middle São Francisco River in Bahia (Sá-Neto \& Marinho-Filho 2013), and in the humid Brejos de Altitude in the Paraíba state (Feijó and Langguth 2011).

Unfortunately, from 30 to $52 \%$ of the Caatinga have already been used to pastures and/or plantations (Aguiar and Zórtea 2008). Our study, and several others (e.g. Silva et al. 2003; Leal et al. 2005; Bernard et al. 2011, Lapenta and Bueno 2015, Feijó et al. 2015 a,b; Carvalho-Neto et al. 2017, Rocha et al. 2015, 2018) highlight the importance of creating new protected areas in still so poorly known Caatinga biome in order to conserve and restore the habitat remnants, and also increase the connectivity of the protected areas. 


\section{ACKNOWLEDGMENTS}

We would like to thank to Mr. Alcir Vale Dourado and IESB / PRESERVA for offering the opportunity to participate of the management plan of RPPN Pé de Serra; Jenna Goodward for her review and suggestions; Leonardo Neves and Gabriel Santos for their fieldwork assistance; Funding for this project was provided by Fundo Nacional do Meio Ambiente - FNMA.

\section{REFERENCES}

Alvarez, J.; Willig, M. R.; Jones Jr., J. K. \& Webster, W. D. 1991. Glossophaga soricina. Mammalian Species 379:1-7.

Bernard, E.; Aguiar, L. M. S. \& Machado, R. 2011. Discovering the Brazilian bat fauna: a task for two centuries? Mammal Review 41(1): 23-39.

Bernard, E. \& Fenton, B. 2003. Bat mobility in a fragmented landscape in Central Amazonia. Biotropica 35:262-277.

Brito, D.; Oliveira, L. C.; Oprea, M. \& Mello, M. A. R. 2009. An overview of Brazilian mammalogy: trends, biases and future directions. Zoologia 26(1):67-73.

Carvalho-Neto, F. G.; Silva, J. R.; Santos, N.; Rohde, C.; Garcia, A. C. L. \& Montes, M. A. 2017. The heterogeneity of Caatinga biome: an overview of the bat fauna. Mammalia 81(3):257-264.

Colwell, R. K. 2013. EstimateS: Statistical estimation of species richness and shared species from samples. Version 9.1.o. Available at: <http://www.purl.oclc. org/estimates>. Accessed on October, 2013.

Estrada-Villegas, S.; McGill, B. \& Kalko, E. K. V. 2012. Determinants of species evenness in a neotropical bat ensemble. Oikos 121:927-941.

Falcão, F. C.; Soares-Santos, B. \& Drummond, S. 2005. Espécies de morcegos do Planalto da Conquista, Bahia, Brasil. Chiroptera Neotropical 11(1-2):220-223.

Faria, D. \& Baumgarten, J. 2007. Shade cacao plantations (Theobroma cacao) and bat conservation in southern Bahia, Brazil. Biodiversity and Conservation 16:291-312.

Feijó, J. A. \& Langguth, A. 2011. Lista de quirópteros da Paraíba, Brasil com 25 novos registros. Chiroptera Neotropical 17(2):1055-1062. 
Faria, D. 2006. Phyllostomid bats of a fragmented landscape in north-eastern Atlantic forest, Brazil. Journal of Tropical Ecology 22:531-542.

Faria, D.; Soares-Santos, B. \& Sampaio, E. 2006. Bats from the Atlantic rainforest of southern Bahia, Brazil. Biota Neotropica 6(2). Available at: <http://www. biotaneotropica.org.br/v6n2/pt/abstract?inventory+bno2406022006>. Accessed on October, 2013.

Fenton, M. B.; Acharya, L.; Audet, D.; Hickey, M. B. C.; Merriman, C.; Obrist, M. K. \& Syme, D. M. 1992. Phyllostomid bats (Chiroptera: Phyllostomidae) as indicators of habitat disruption in the Neotropics. Biotropica 24(30):440-446.

Gardner, A. L. 2007. Mammals of South America - Marsupials, Xenarthrans, Shrews and Bats. v.1, The University of Chicago Press. 669p.

Giannini, N. P. \& Kalko, E. K. V. 2004. Trophic structure in a large assemblage of phyllostomid bats in Panama. Oikos 105:209-220.

Gorrensen, P. M. \& Willig, M. R. 2004. Landscape responses of bats to habitat fragmentation in Atlantic forest of Paraguay. Journal of Mammalogy 85(4):688-697.

Gotelli, N. J. \& Colwell, R. K. 2001. Quantifying biodiversity: procedures and pitfalls in the measurement and comparison of species richness. Ecology Letters 4:379-391.

Gregorin, R. \& Mendes, L. F. 1999. Sobrequirópteros (Emballonuridae, Phyllostomidae, Natalidae) de duas cavernas da Chapada Diamantina, Bahia, Brasil. Iheringia, Série Zoologia 86:121-124.

Gregorin, R.; Carmignotto, A. P. \& Percequillo, A. R. 2008. Quirópteros do Parque da Serra das Confusões, Piauí, nordeste do Brasil. Chiroptera Neotropical 14(1):366383.

IBGE - Instituto Brasileiro de Geografia e Estatística. 2004. Mapa de Biomas do Brasil. Rio de Janeiro, IBGE/MMA.

Kalko, E. 1997. Diversity in tropical bats. In: Kunz, T. H. ed. Tropical Biodiversity and systematics: Proceedings of the International Symposium on Biodiversity and Systematics in Tropical Ecosystems. Bonn, Zoologisches Forschungsinstitut und Museum Alexander Koenig. p.13-43.

Kalko, E. K. V. 1998. Organization and diversity of tropical bat communities through space and time. Zoology 101:281-297. 
Kunz, T. H. \& Kurta, A. 1988. Capture methods and holding devices. In: Kunz, T. H. ed. Ecological and behavioral methods for the study of bats. Washington, D.C., Smithsonian Institution Press. p.1-29.

Kottek, M.; Grieser, J.; Beck, C.; Rudolf, B. \& Rubel, F. 20o6. World Map of the KöppenGeiger climate classification updated. Meteorologische Zeitschrift 15(3):259-263.

Leal, I. R.; Silva, J. M. C.; Tabarelli, M. \& Lacher Jr., T. E. 2005. Mudando o curso da conservação da biodiversidade na Caatinga do Nordeste do Brasil. Megadiversidade 1(1):139-146.

Lewinsohn, T. M. 2006. Avaliação do estado do conhecimento da biodiversidade brasileira. Brasília, MMA. 520p.

Lim, B. K. \& Engstrom, M. D. 2001. Species diversity of bats (Mammalia: Chiroptera) in Iwokrama Forest, Guyana, and the Guianan subregion: implications for conservation. Biodiversity and Conservation 10:613-657.

Marinho-Filho, J. \& Sazima, I. 1998. Brazilian bats and conservation biology: a first survey. In: T. H. Kunz \& P. A. Racey. eds. Bat Biology and Conservation. Washington D.C., Smithsonian Institution Press. p.282-294.

McAleece, N.; Gage, J. D. G.; Lambshead, P. J. D. \& Paterson, J. L. G. 1997. BioDiversity Professional statistical analysis. Available at: <http://www.sams.ac.uk/peterlamont/biodiversity-pro>. Accessed on October, 2013.

McSwiney, M. C.; Clarke, F. M. \& Racey, P. 2008. What you see is not what you get: the role of ultrasonic detectors in increasing inventory completeness in Neotropical bat assemblages. Journal of Applied Ecology 45:1364-1371.

Medellín, R. A.; Equihua, M. \& Almin, M. A. 2000. Bat diversity and abundance as indicators of disturbance in Neotropical rainforests. Conservation Biology 14(6):1666-1675.

MorATElli R. \& DiAs D. (2015) A new species of nectar-feeding bat, genus Lonchophylla, from the Caatinga of Brazil (Chiroptera, Phyllostomidae). ZooKeys, 514: 73-91. doi: 10.3897/zookeys.514.10013

Feijó J.A., Rocha P.A. \& Althoff S.L. 2015. New species of Histiotus (Chiroptera: Vespertilionidae) from northeastern Brazil. Zootaxa, 4048(3): 412-427. doi: 10.11646/ zootaxa.4048.3.4 
Feijó J.A., Rocha P.A., Mikalauskas J.S. \& Ferrari S.F. 2015b. Macrophyllum macrophyllum (Schinz, 1821) in the Brazilian Caatinga scrublands: river basins as potential routes of dispersal in xeric ecosystems. Mastozoologia Neotropical 22(1): $1-7$.

Paglia A.P.; Fonseca, G.A.B.; Rylands, A.B.; Herrmann G.; Aguiar, L.M.S.; Chiarello, A.G.; Leite Y.L.R.; Costa L.P.; Siciliano S. \& Kierulff M.C.M, Sérgio L. Mendes, V. da C. Tavares, V. da C., Mittermeier, R.A. \& J. L. Patton. 2012. Lista anotada dos mamíferos do Brasil. $2^{\circ}$ edição. Occasional Papers of Conservation Biology, 6: 1-76.

Peracchi, A. L. \& Nogueira, M. R. 2007. Família Emballonuridae. In: Reis, N. R.; Peracchi, A. L.; Pedro, W. A. \& Lima, I. P. orgs. Morcegos do Brasil. Londrina. p.2736.

Nogueira, M. R.; Peracchi, A. L. \& Moratelli, R. 2007. Subfamília Phyllostominae. In: Reis, N. R.; Peracchi, A. L.; Pedro, W. A. \& Lima, I. P. orgs. Morcegos do Brasil. Londrina. p.61-97.

Nowak, R. 1994. Walker's Bats of the World. Baltimore and London, The Johns Hopkins University Press. 287p.

Patterson, B. D.; Willig, M. R. \& Stevens, R. D. 2003. Trophic strategies, niche partitioning, and patterns of ecological organization. In: Kunz, T. H. \& Fenton, M. B. eds. Bat Ecology. Chicago, The University of Chicago Press. 536-579p.

Rios, G. F. P.; Sá-Neto, R. J. \& Graciolli, G. 20o8. Fauna de dípteros parasitas de morcegos em uma área de Caatinga do nordeste do Brasil. Chiroptera Neotropical 14(1):339-345.

Rocha, P.A., Feijó J.A., Pedroso M.A. \& Ferrari S.F. 2015. First record of the big free-tailed bat, Nyctinomops macrotis (Chiroptera, Molossidae), for the semi-arid Caatinga scrublands of northeastern Brazil. Mastozoología Neotropical, 22(1): 195200.

Rocha P.A., Pedroso M.A. \& Velazco P.M. 2018 First record of Platyrrhinus fusciventris (Chiroptera, Phyllostomidae) for the Caatinga biome. Mammalia, 82(2): 178-182. doi: 10.1515/mammalia-2016-0170

Sá, I. B.; Riché, G. R. \& Fotius, G. A. 2003. As paisagens e o processo de degradação do semi-árido nordestino. In: Silva, J. M. C.; Tabarelli, M.; Fonseca, M. T. \& Lins, L. V. eds. Biodiversidade da Caatinga: áreas e ações prioritárias para a conservação. Brasília, MMA. p.17-36. 
Sá-Neto, R.J. \& J. Marinho-Filho. 2013. Bats in fragments of xeric woodland Caatinga in Brazilian semiarid. Journal of Arid Environments. 90: 88-94.

Sbragia, I.A. \& Cardoso, A. 2008. Quiropterofauna (Mammalia: Chiroptera) cavernícola da Chapada Diamantina, Bahia, Brasil. Chiroptera Neotropical 14(1):360-365.

Schnitzler, H.-U. \& Kalko, E. K. V. 1998. How echolocating bats search and find food. In: Kunz, T. H. \& Racey, P. A. eds. Bat Biology and Conservation. Washington and London, Smithsonian Institution Press. p.183-196.

Schulze, M. D.; Seavy, N. E. \& Whitacre, D. F. 2000. A comparison of phyllostomid bat assemblages in undisturbed Neotropical forest and in forest fragments of a slash-andburn farming mosaic in Petén, Guatemala. Biotropica 32:174-184.

Silva, J. M. C.; Tabarelli, M.; Fonseca, M. T. \& Lins, L. V. 2003. Biodiversidade da Caatinga: áreas e ações prioritárias para a conservação. Brasília, MMA. 382p.

Simmons, N. B. \& Voss, R. S. 1998. The Mammals of Paracou, French Guiana: a Neotropical lowland rainforest fauna. Part 1. Bats. Bulletin of the American Museum of Natural History 237:1-219.

Straube, F. C. \& Bianconi, G. V. 2002. Sobre a grandeza ea unidade utilizada para estimar esforço de captura com utilização de redes-de-neblina. Chiroptera Neotropical 8(12):150-152.

Tavares, V. C., Gregorin, R. \& Peracchi, A. L. 2008. A diversidade de morcegos no Brasil: lista atualizada com comentários sobre distribuição e taxonomia. In: Pacheco S. M.; Marques R. V.; Esbérard C. E. orgs. Morcegos do Brasil: Biologia, Sistemática, Ecologia e Conservação. Porto Alegre, Armazém Digital. p. 25-6o.

Trajano, E. 1996. Protecting caves for the bats or bats for the caves? Chiroptera Neotropical 1:19-22.

Vizotto, L. D. \& Taddei, V. A. 1973. Chave para determinação de quirópteros brasileiros. Revista da Faculdade de Ciências e Letras de São José do Rio Preto, Boletim de Ciências 1:1-72.

Wilson, D. E. 1975. Bat faunas: a trophic comparison. Systematic Zoology 22:14-29. 
Table 1 - List of bats recorded in the RPPN Pé de Serra, Ibotirama, Bahia, northeastern Brazil. Feeding guilds: frugivore- FR, omnivore - ON, sanguinivore - SA, nectarivore - NE, gleaning insectivore - GI, aerial insectivore - AI, and carnivore - CA.

\begin{tabular}{llcc}
\hline \multicolumn{1}{c}{ Taxon } & N (\%) & Feeding Guild \\
\hline \multirow{2}{*}{ Emballonuridae } & Peropteryx macrotis (Wagner 1843) & $1(1,8 \%)$ & AI \\
& Saccopteryx leptura (Schreber, 1774) & $1(1,8 \%)$ & AI \\
\hline \multirow{5}{*}{ Phyllostomidae } & Artibeus planirostris (Spix, 1823) & $15(27,3 \%)$ & FR \\
& Artibeus obscurus (Schinz, 1821) & $6(10,9 \%)$ & FR \\
& Carollia perspicillata (Linnaeus, 1758) & $11(20 \%)$ & FR \\
& Chrotopterus auritus (Peters, 1856) & $2(3,6 \%)$ & CA \\
& Desmodus rotundus (É. Geoffroy, 1810) & $1(1,8 \%)$ & SA \\
& Glossophaga soricina (Pallas, 1766) & $6(10,9 \%)$ & NE \\
& Phyllostomus hastatus (Pallas, 1767) & $2(3,6 \%)$ & ON \\
& Platyrrhinus lineatus (É. Geoffroy, 1810) & $9(16,4 \%)$ & FR \\
& Micronycteris minuta (Gervais, 1856) & $1(1,8 \%)$ & GI \\
\hline
\end{tabular}

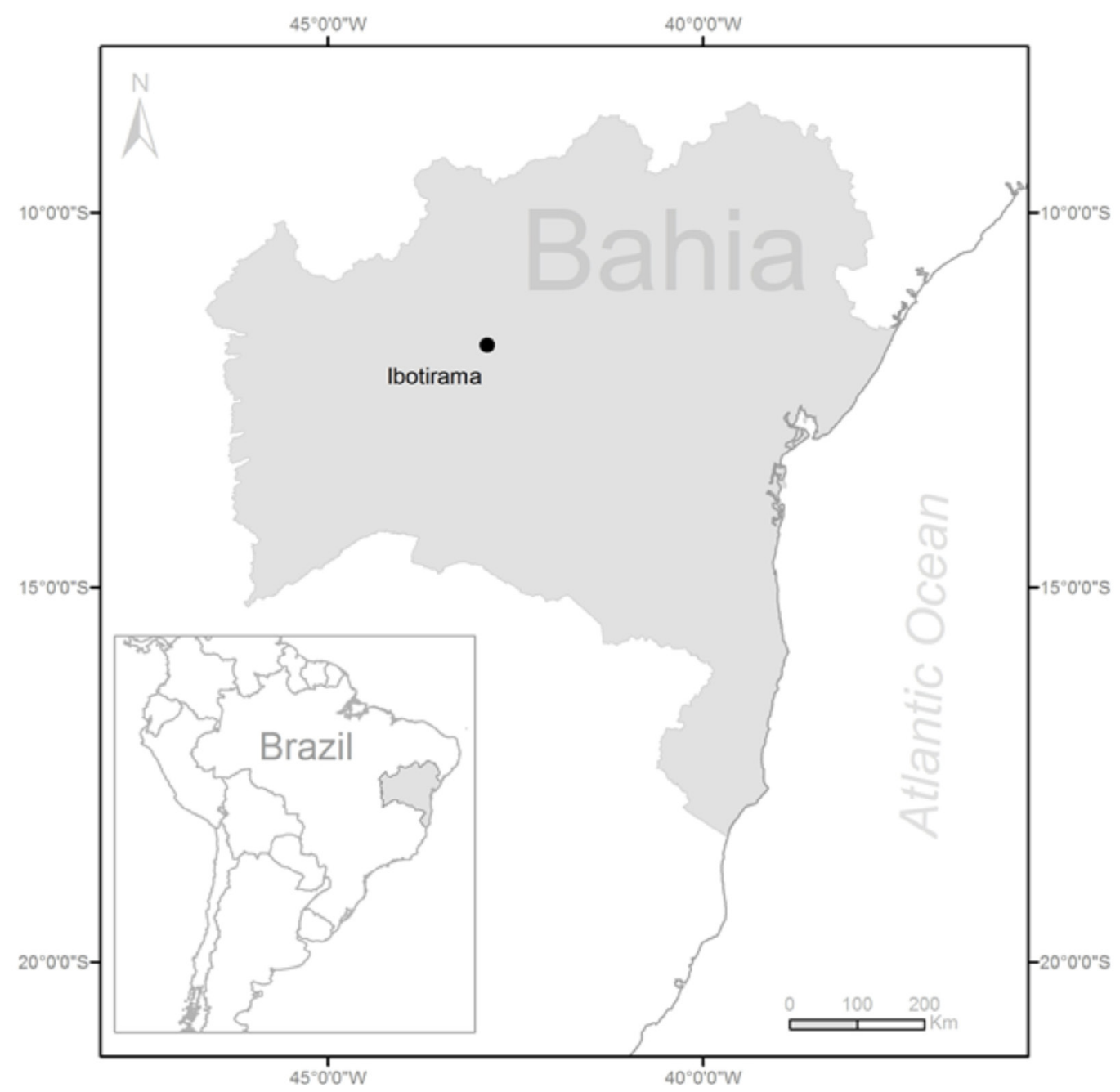

Figure 1 - Location of municipality of Ibotirama, Bahia, northeastern Brazil. 


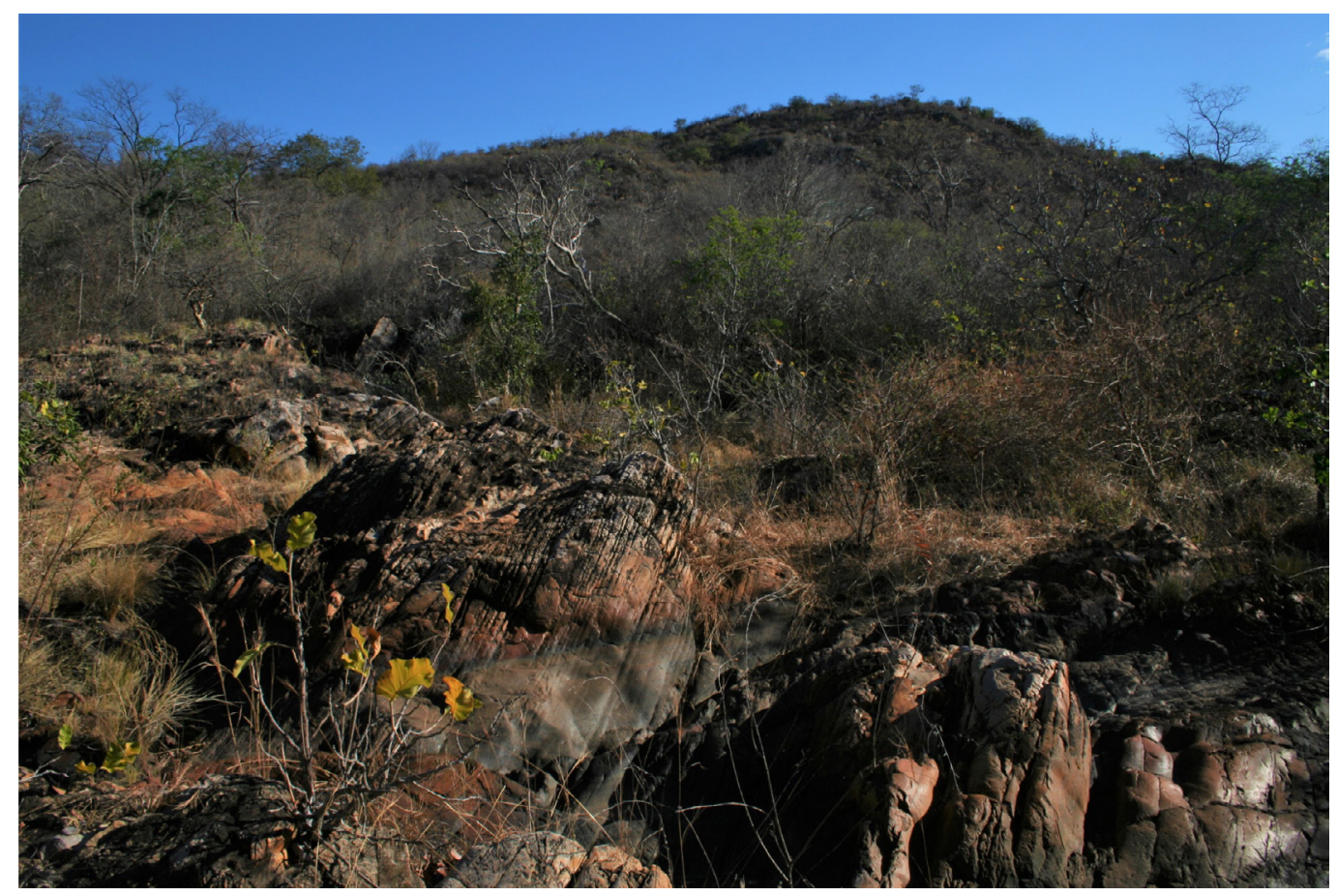

Figure 2 - Xerophylic vegetation present in RPPN Pé de Serra, Ibotirama, in the Caatinga biome.

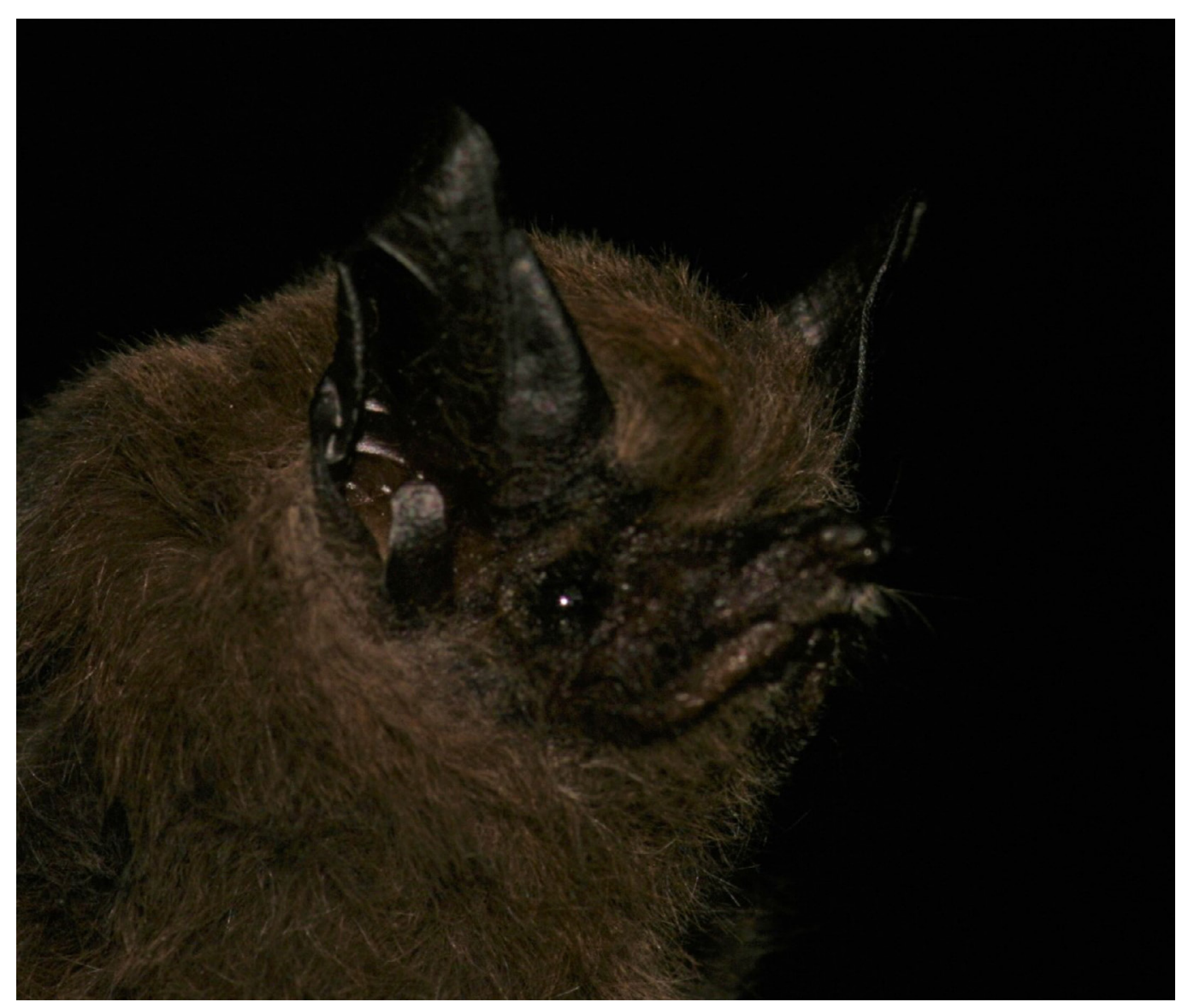

Figure 3 -Saccopteryx leptura, an insectivorous species found during searches in diurnal roosts in the Reserve. 


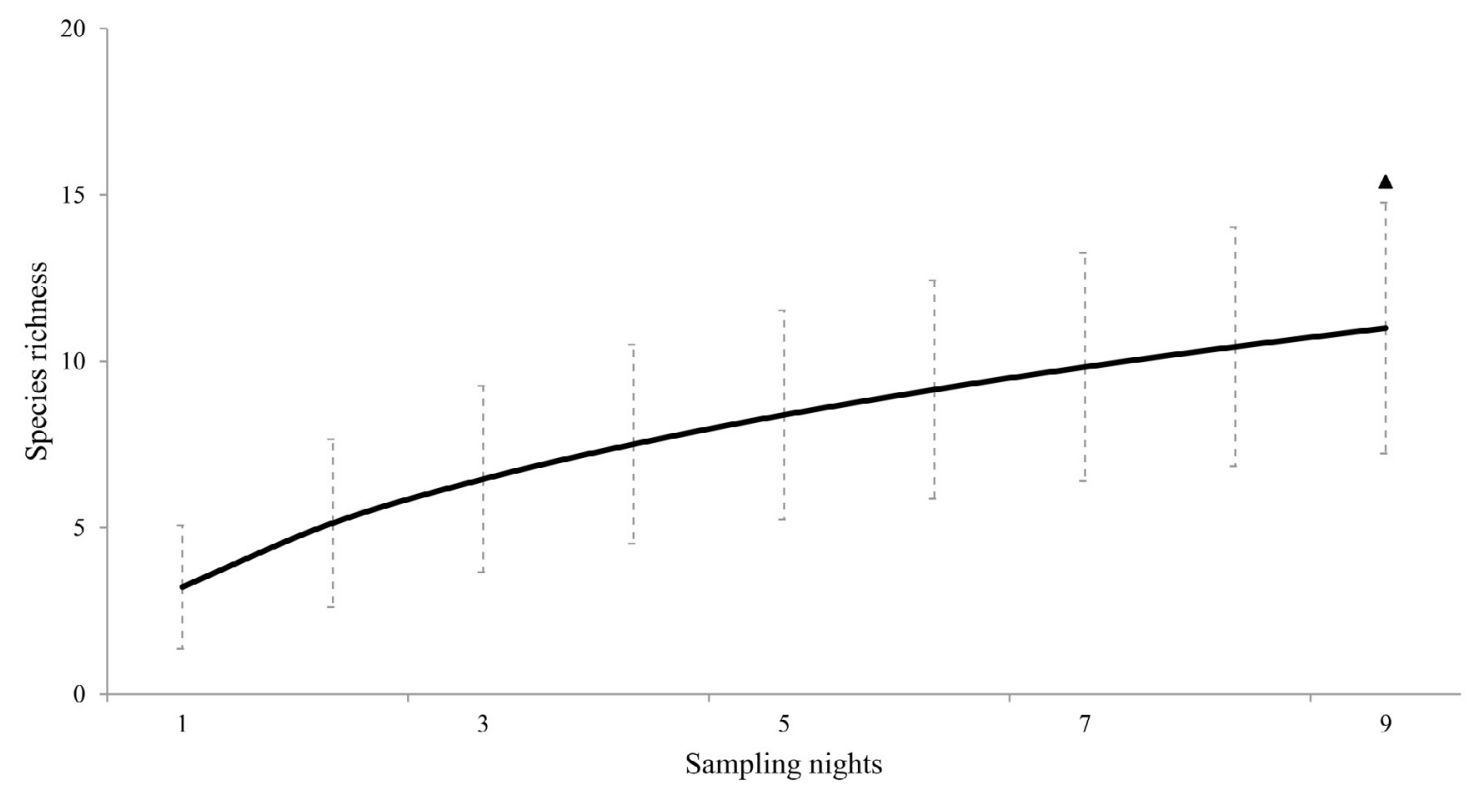

Figure 4 - Species accumulation curve with 95\% confidence intervals and Jackknife 1 richness estimator $(\boldsymbol{\Delta})$ for the bat fauna of RPPN Pé de Serra, Ibotirama, Brazil.

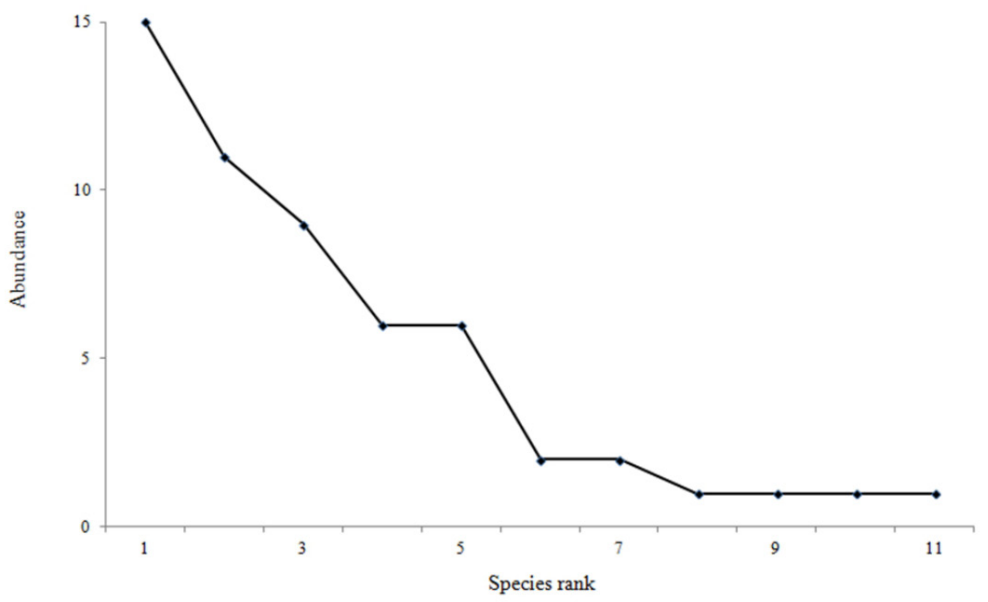

Figure 5 - Rank abundance plot for the bat fauna of RPPN Pé de Serra, Ibotirama, Brazil. 